\title{
Validation of a questionnaire for the evaluation of clinical competencies in nutrition
}

Recibido: 14 de octubre de 2019 / Revisado: 23 de octubre de 2019

Aceptado: 17 de noviembre de 2019 / Publicado: 20 de diciembre de 2019

MAURICIO BRETÓN DE LA LOZA MARTÍN

Jefe del Departamento de Transferencia de Conocimientos, Facultad de Nutrición,

Universidad Autónoma del Estado de Morelos, México.

martin.breton@uaem.mx

JAQUELINE GUADALUPE GUERRERO CEH

Profesor Investigador de Tiempo Completo,

Universidad Internacional Iberoamericana, México.

jgguerre@uacam.mx

OFMARA YADIRA ZÚÑIGA HERNÁNDEZ

Profesor Investigador de Tiempo Completo, Instituto de Ciencias de la Educación,

Universidad Autónoma del Estado de Morelos, México.

ofmara.zuniga@uaem.mx

LAURA TATIANA CERVANTES RAMÍREZ

Profesor Adscrito a la Facultad de Nutrición,

Universidad Autónoma del Estado de Morelos. México.

tatianacervantes_rmz@hotmail.com

SARA DIANA GARDUÑO DÍAZ

Profesor Investigador de Tiempo Completo, Instituto de Ciencias de la Educación, Universidad Autónoma del Estado de Morelos, México.

sony@uaem.mx

SONALÍ CARRANCO GÓMEZ

Jefa de Departamento de Investigacion y Desarrollo,

Invincible Brands, Alemania.

sdgarduno@gmail.com

MARÍA ALEJANDRA TERRAZAS MERAZ

Profesor Investigador de Tiempo Completo, Facultad de Nutrición, Universidad Autónoma del Estado de Morelos.

maria.alejandra@uaem.mx 


\section{ABSTRACT}

Today's educational challenges require linking theory and practice in real settings to ensure meaningful learning and to respond to the social commitment of higher education institutions. At the Universidad Autónoma del Estado de Morelos (UAEM), nutrition studies follow the competency-based educational model. It is thus important to know the level of basic clinical competencies (Clinical History, Physiopathology, Procedures) that students of the Bachelor's Degree in Nutrition have. Objective: To validate an instrument that allows the evaluation of the level of basic clinical competencies acquired by the students enrolled in the Degree in Nutrition. Design and methodology: This is an analytical cross-sectional observational study. All students enrolled at the beginning of the PAR-2018 semester $(\mathrm{N}=1018)$ were included as target population. The sample size was calculated by the formula for obtaining proportions with correction for finite population proposed in Daniel's book (2005), yielding as a minimum size a $\mathrm{n}=280$ students, to potentiate the statistical study all students surveyed were included. In the first instance, the instrument was validated through 5 academicpairs using the Delphi system, the reliability through Cronbach's alpha and the main component tests for the exploratory factorial analysis and Spearman's for the confirmatory analysis. In order to validate the linear relationship with the semester studied, ANOVA and Bonferroni were used, based on the use of the statistical program Stata ${ }^{\circledR}$ v.14. Results: The questionnaire was applied to 622 students from first to eighth semester, 469 (75.4\%) are women and 153 (24.6\%) are men. The reliability of the scales resulted with Chronbach Alphas greater than 0.7. Conclusions The validated proposal of a questionnaire to evaluate clinical competencies is presented to students of Bachelor in Nutrition.

Keywords: assessment methods, competency-based education, nutrition, questionnaries.

\section{Background}

In recent decades, the importance of linking professionalization with the corresponding needs for job performance has been recognized, and competency-based educational models in educational institutions have been disseminated worldwide. In January 2006, the Faculty of Medicine of the University of Montreal undertook a renewal project to foster competencies in many roles expected of them throughout their careers. The CPASS (Centre for Applied Pedagogy to Health Sciences) conducted a study with 100 health residents who participated in a series of meetings and training sessions, as well as consultations, validation and outreach activities (Boucher, 2014).

This trend is present in Mexico mainly in the technical, upper-middle and upper-middle areas, and naturally in the area of Health Sciences. (García García, 2010) However, the reforms suffered in our educational system in this century respond to a certain extent to the demands of the organizations that are promoting the educational model by competencies at a global level. Unfortunately, the most important proposals, such as the Tuning Project (2007), the DeSeCo Project (2006) and the OECD (1994), which include this training model, do not consider clinical competencies or the degree of Licenciado en Nutrición Humana (Moreno Olivos, 2010). Particularly in the area of Health Sciences, one of the most challenging tasks is the evaluation of students' clinical competencies in an objective 
manner, considering the complexities involved in the system of patient care (Canicoba, Baptista and Visconti, 2013). According to several authors who have tried to conceptualize and measure them, these are defined as a psychological construct that includes cognitive, emotional, psychomotor skills, critical thinking and problem solving, which in turn incorporate knowledge, values and attitudes (Freed, 1998; Anderson and Stickley, 2002; watson, 2002, McGaughey, 2004; Cowan, Norman and Coopamah, 2005; Defloor et al., 2006; Tobón, 2007 ; Walsh, 2009 ; Díaz-Lorenzo et al., 2011; Gracía, 2010; Rivera-Michelena, 2017).

On the international scale, competition is defined as the "complex ability to act, which is supported by the mobilization and efficient combination of a variety of internal and external resources within a family of situations" (Tardif, 2006, p.22). Studies found, such as (Dix, 2005, Sepulveda Vildosola, 2014), mention that the design and validation of instruments that measure the level of competencies that an individual has, is of vital importance to be able to evidence, establish and ensure professional know-how (Márquez Sandoval et al, 2014, Villavicencio Martínez, 2017). In the theoretical revision proposed by Corvalán et al. (Rangel-Torrijo, 2015), it is recognized that the evaluation of competencies is interesting because it emphasizes the necessary validity and reliability. It should be remembered that assessment is the area that represents a challenge in practice and in the curricular perspective of competencies due to its dynamic nature, especially in the field of health. In this sense, the Center for Applied Pedagogy of the Faculty of Medicine of the University of Montreal is an example of the integral structure for developing competent professional behaviors (Boucher, 2014).

The development of clinical competencies is an essential part of academic training in the area of health, since they are fundamental elements for comprehensive patient care; however, the objective analysis of these capabilities is scarce; both from the conceptual perspective and from the instruments available to carry it out. Most of these instruments evaluate a single competence or, at best, two (Regehr, 2011). The instruments available can be divided into three categories: formal, structured, circumscribed and ex vivo evaluations (written, oral or ECOE examinations); formal, structured, circumscribed in situ examinations (Mini Clinical Evaluation Exercise or mini-CEX); and informal, unstructured, summative, in situ evaluations (In-trining Evaluation Report) (Cook et al., 2011). From an educational perspective, the assessment of clinical competence requires direct observation of the clinical skills of the learner and the use of valid and reliable instruments that objectify the process.

The Degree in Nutrition has become increasingly relevant in the context of global health issues, and has a general approach to the whole range of professional insertion, which includes nutrition with a clinical focus (Canicoba et al., 2013).

Currently, the approaches for the measurement of clinical competencies have been developed and implemented performed in the areas of medicine, stomatology, podiatry, occupational therapy, physio- 
therapy, radiotherapy and nursing (Rushton, 2003; Walsh, 2009; De Zousa Cruz 2016); however, it is important to recognize that the degree of these skills in these disciplines is heterogeneous, and therefore, their human resources must have knowledge and skills specific to their functions and professional deontology. In this sense, several authors agree that it is necessary that the Nutrition Degree oriented to clinical practice possesses deep theoretical and technical knowledge for an optimal development in this area, as well as artificial nutritional support, which assures an effective professional exercise with the capacity to solve the problems corresponding to the nutritional attention of in-hospital patients (Sánchez, 2003; Sierra Figaredo, 2010; Díaz- Lorenzo et al., 2011).

In Morelos, Mexico, the Bachelor's Degree in Nutrition arose as an educational offer from the Autonomous University of the State of Morelos (UAEM) in February 2009, as a response to the growing demand of the population of students with a vocation for Health Science (UAEM, 2010). It focuses on the need to ensure that its graduates have the theoretical-practical knowledge that will allow them to perform optimally in the workplace and enable them to solve problems in various specialty areas, including clinical nutrition. During the period 2013 - 2018, 4 agreements were cancelled for the performance of professional practices and the provision of social service in the area of clinical nutrition, which represent little more than 40 occupational positions in the different clinical fields offered by the public and private sector (Data provided by the Head of Professional Practices and Social Service of the Faculty of Nutrition 2018). This phenomenon has forced the authorities of the Faculty of Nutrition (FN), to identify the possible factors that have triggered this problem, including assessing that students in the final stage of the bachelor's degree have the clinical skills necessary to enable them to perform efficiently their academic and work activities in this field. Therefore, this study aims to generate diagnostic measures of basic clinical skills from the validation of a questionnaire evaluating theoretical-practical knowledge on clinical history, physiopathology and technical procedures in students of the FN- UAEM Degree. The aim of this article is to contribute to the justification of why a method is necessary for the evaluation of competencies and to determine how these are interrelated as a result of a process that takes place from theoretical-practical actions and interventions, fundamentally in the field of nutrition.

\section{Design and methodology}

This is an analytical cross-sectional study carried out for the validation of an instrument (questionnaire) for the evaluation of clinical competencies necessary for the training of students of the Degree in Nutrition. The study population included all students enrolled on February 27, 2018 in the 
Nutrition Degree of the Faculty of Nutrition of the Autonomous University of the State of Morelos (UAEM), in Mexico (N=1018), of which 758 (74.4\%) were women and 260 (25.6\%) men. The sample size was calculated by the probabilistic formula with finite population correction (Daniel, 2005), resulting in a minimum sample size of 280 subjects, an invitation was made to participate in the study and those individuals who met the inclusion criteria for this study obtained randomly were included. In addition, a Likert type questionnaire (Matas, 2018) was developed at five llevels to evaluate three basic clinical competencies (clinical history, pathophysiology and technical procedures), made up of 71 items divided into three sections: clinical history (18 items), pathophysiology (29 items) and procedures (24 items). Based on the Official Mexican Standards NOM-004-SSA3-2012; NOM-022SSA3-2012; NOM-249-SSA1-2010; NOM149-SSA1-1996, the items were constructed, which were evaluated in their construction by the "round of experts" method, which was carried out by peers among five academic specialists, both in the area of clinical nutrition and competencies.

After its application, the level of reliability (internal validity) of the instrument was evaluated with Cronbach's Alpha statistic (Quero-Virla, 2010); Regarding the coherence between the items to evaluate each competence, a factorial analysis of main components with orthogonal rotation was carried out as exploratory analysis and Spearman's correlation method was used for confirmatory analysis. Likewise, the relationship with sociodemographic variables was reviewed with Mann-Whitney's U tests, KruskalWallis and ANOVA of a pathway with Bonferroni's revision (Daniel, 2005). STATA® version 14 (StataCorp, 2015) was used for statistical management of the data.

\section{Results}

A total of 622 students were included in the study, Table 1 describes the general characteristics compared by sex, a primordial presence of women is observed $(n=469 ; 75.4 \%)$, the ages oscillate between 18 and 47 years, with an average of 21.4 years for men as opposed to 21.1 for women $(\mathrm{p}<0.05)$, the socioeconomic index (Bronfman, 1988) is with greater frequency in bad level. As for the results of the application of the knowledge questionnaire, tables 2, 3 and 4 show the response frequencies per item and mark the correct answer shaded. There were no responses with more than $80 \%$ frequency, which allows us to treat the items as unbiased to be included in the factor analysis of main components. 
Table 1: Socio-demographic variables by gender.

\begin{tabular}{|c|c|c|c|c|c|c|c|c|}
\hline \multirow[t]{2}{*}{ Variable/category } & \multicolumn{2}{|c|}{ Women $(n=469) 75.4 \%$} & \multicolumn{2}{|c|}{ Men $(n=153) 24.6 \%$} & \multicolumn{2}{|c|}{ Total $(n=622)$} & \multirow[t]{2}{*}{$\square^{2}$} & \multirow[t]{2}{*}{ Sig. } \\
\hline & Obs & $\%$ & Obs & $\%$ & Obs & $\%$ & & \\
\hline \multicolumn{9}{|l|}{ AGE } \\
\hline Below 21 & 216 & 46.1 & 55 & 35.9 & 271 & 43.6 & 4.8 & 0.029 \\
\hline 21 o older & 253 & 53.9 & 98 & 64.1 & 352 & 56.4 & & \\
\hline \multirow[t]{2}{*}{ INSE (n=609) } & & & & & Total & & & \\
\hline & & & & & Students & $\%$ & & \\
\hline Poor & 77 & 16.7 & 36 & 24.5 & 113 & 18.6 & & \\
\hline Regular & 224 & 48.5 & 66 & 44.9 & 290 & 47.7 & & \\
\hline Good & 161 & 34.8 & 45 & 30.6 & 206 & 33.8 & & \\
\hline Total & 462 & & 147 & & 609 & & & \\
\hline
\end{tabular}

Source: Questionnaire to students of Bachelor in Nutrition 2018.

Table 2. Frequency of responses for medical history competency assessment $(n=622)$

\begin{tabular}{|c|c|c|c|c|c|c|c|}
\hline Key & & 1 & 2 & 3 & 4 & 5 & Non-respondant \\
\hline \multirow[t]{2}{*}{$\mathrm{HC} 1$} & $\mathbf{n}$ & 28 & 25 & 85 & 211 & 279 & \\
\hline & $\%$ & 4.4 & 3.9 & 13.5 & 33.6 & 44.4 & \\
\hline \multirow[t]{2}{*}{$\mathrm{HC} 2$} & $\mathbf{n}$ & 112 & 32 & 28 & 82 & 374 & \\
\hline & $\%$ & 17.8 & 5.1 & 4.4 & 13.0 & 59.5 & \\
\hline \multirow[t]{2}{*}{$\mathrm{HC} 3$} & $\mathbf{n}$ & 109 & 46 & 51 & 95 & 327 & \\
\hline & $\%$ & 17.3 & 7.3 & 8.1 & 15.1 & 52.0 & \\
\hline \multirow[t]{2}{*}{$\mathrm{HC} 4$} & $\mathbf{n}$ & 153 & 80 & 182 & 128 & 84 & 1 \\
\hline & $\%$ & 24.3 & 12.7 & 28.9 & 20.3 & 13.3 & 0.16 \\
\hline \multirow[t]{2}{*}{ HC5 } & $\mathbf{n}$ & 88 & 30 & 246 & 111 & 151 & 2 \\
\hline & $\%$ & 14.0 & 4.7 & 39.1 & 17.6 & 24.0 & 0.32 \\
\hline \multirow[t]{2}{*}{ HC6 } & $\mathbf{n}$ & 22 & 11 & 51 & 176 & 368 & \\
\hline & $\%$ & 3.5 & 1.7 & 8.1 & 28.0 & 58.6 & \\
\hline \multirow[t]{2}{*}{$\mathrm{HC} 7$} & $\mathbf{n}$ & 33 & 20 & 66 & 178 & 331 & \\
\hline & $\%$ & 5.2 & 3.1 & 10.5 & 28.3 & 52.7 & \\
\hline \multirow[t]{2}{*}{$\mathrm{HC} 8$} & $\mathbf{n}$ & 116 & 69 & 179 & 77 & 187 & \\
\hline & $\%$ & 18.4 & 10.9 & 28.5 & 12.2 & 29.7 & \\
\hline
\end{tabular}




\begin{tabular}{|c|c|c|c|c|c|c|c|}
\hline Key & & 1 & 2 & 3 & 4 & 5 & Non-respondant \\
\hline \multirow[t]{2}{*}{$\mathrm{HC} 9$} & $\mathbf{n}$ & 77 & 52 & 188 & 169 & 141 & 1 \\
\hline & $\%$ & 12.2 & 8.2 & 29.9 & 26.9 & 22.4 & 0.2 \\
\hline \multirow[t]{2}{*}{$\mathrm{HC} 10$} & $\mathbf{n}$ & 126 & 148 & 145 & 91 & 117 & 1 \\
\hline & $\%$ & 20.0 & 23.5 & 23.0 & 14.4 & 18.6 & 0.2 \\
\hline \multirow[t]{2}{*}{ HC11 } & $\mathbf{n}$ & 96 & 47 & 54 & 97 & 333 & 1 \\
\hline & $\%$ & 15.2 & 7.4 & 8.6 & 15.4 & 53.0 & 0.2 \\
\hline \multirow[t]{2}{*}{$\mathrm{HC} 12$} & $\mathbf{n}$ & 92 & 48 & 74 & 299 & 114 & 1 \\
\hline & $\%$ & 14.6 & 7.6 & 11.7 & 47.6 & 18.1 & 0.2 \\
\hline \multirow[t]{2}{*}{$\mathrm{HC} 13$} & $\mathbf{n}$ & 106 & 40 & 66 & 109 & 306 & 1 \\
\hline & $\%$ & 16.8 & 6.3 & 10.5 & 17.3 & 48.7 & 0.2 \\
\hline \multirow[t]{2}{*}{$\mathrm{HC} 14$} & $\mathbf{n}$ & 116 & 51 & 65 & 105 & 290 & 1 \\
\hline & $\%$ & 18.4 & 8.1 & 10.3 & 16.7 & 46.1 & 0.2 \\
\hline \multirow[t]{2}{*}{$\mathrm{HC} 15$} & $\mathbf{n}$ & 117 & 41 & 96 & 97 & 276 & 1 \\
\hline & $\%$ & 18.6 & 6.5 & 15.2 & 15.4 & 43.9 & 0.2 \\
\hline \multirow[t]{2}{*}{$\mathrm{HC} 16$} & $\mathbf{n}$ & 38 & 24 & 73 & 204 & 289 & \\
\hline & $\%$ & 6.05 & 3.8 & 11.6 & 32.4 & 46.0 & \\
\hline \multirow[t]{2}{*}{$\mathrm{HC} 17$} & $\mathbf{n}$ & 92 & 56 & 204 & 88 & 188 & \\
\hline & $\%$ & 14.6 & 8.9 & 32.4 & 14.0 & 29.9 & \\
\hline \multirow[t]{2}{*}{ HC18 } & n & 95 & 95 & 217 & 127 & 93 & 1 \\
\hline & $\%$ & 15.1 & 15.1 & 34.5 & 20.2 & 14.8 & 0.2 \\
\hline
\end{tabular}

Note: The question key is constructed by $\mathrm{HC}=$ clinical history and the consecutive item number (see Annex 1). Scale: 1: Totally disagree, 2: Partially disagree, 3: Neither agree nor disagree, 4: Partially agree, 5: Totally agree. Source: Questionnaire to students of Bachelor in Nutrition 2018.

Table 3. Frequency of responses for the assessment of physiopathology competencies $(n=622)$

\begin{tabular}{|l|c|c|c|c|c|c|c|}
\hline \multicolumn{1}{|c|}{ Key } & & $\mathbf{1}$ & $\mathbf{2}$ & $\mathbf{3}$ & $\mathbf{4}$ & $\mathbf{5}$ & Non-respondant \\
\hline FP19 & $\mathbf{n}$ & 32 & 34 & 280 & 155 & 127 & \\
\hline & $\boldsymbol{\%}$ & 5.1 & 5.4 & 44.5 & 24.6 & 20.2 & 1 \\
\hline FP20 & $\mathbf{n}$ & 26 & 33 & 235 & 190 & 143 & 0.2 \\
\hline & $\boldsymbol{\%}$ & 4.1 & 5.2 & 37.4 & 30.2 & 22.7 & 1 \\
\hline FP21 & $\mathbf{n}$ & $\mathbf{1 4 6}$ & 203 & 151 & 59 & 68 & 0.2 \\
\hline & $\mathbf{\%}$ & $\mathbf{2 3 . 2}$ & 32.3 & 24.0 & 9.3 & 10.8 & 1 \\
\hline FP22 & $\mathbf{n}$ & $\mathbf{9 1}$ & 150 & 229 & 87 & 70 & 0.2 \\
\hline
\end{tabular}




\begin{tabular}{|c|c|c|c|c|c|c|c|}
\hline Key & & 1 & 2 & 3 & 4 & 5 & Non-respondant \\
\hline \multirow[t]{2}{*}{ FP23 } & $\mathbf{n}$ & 70 & 140 & 234 & 102 & 81 & 1 \\
\hline & $\%$ & 11.1 & 22.2 & 37.2 & 16.2 & 12.9 & 0.2 \\
\hline \multirow[t]{2}{*}{ FP24 } & $\mathbf{n}$ & 172 & 162 & 164 & 47 & 82 & 1 \\
\hline & $\%$ & 27.3 & 25. & 26.1 & 7.4 & 13.0 & 0.2 \\
\hline \multirow[t]{2}{*}{ FP25 } & $\mathrm{n}$ & 40 & 44 & 197 & 188 & 157 & 2 \\
\hline & $\%$ & 6.3 & 7.0 & 31.3 & 29.9 & 25.0 & 0.3 \\
\hline \multirow[t]{2}{*}{ FP26 } & $\mathbf{n}$ & 36 & 34 & 364 & 130 & 63 & 1 \\
\hline & $\%$ & 5.7 & 5.4 & 57.9 & 20.7 & 10.0 & 0.2 \\
\hline \multirow[t]{2}{*}{ FP27 } & $\mathbf{n}$ & 43 & 89 & 352 & 78 & 65 & 1 \\
\hline & $\%$ & 6.8 & 14.1 & 56.0 & 12.4 & 10.3 & 0.2 \\
\hline \multirow[t]{2}{*}{ FP28 } & $\mathbf{n}$ & 42 & 73 & 338 & 88 & 85 & 2 \\
\hline & $\%$ & 6.6 & 11.6 & 53.8 & 14.0 & 13.5 & 0.3 \\
\hline \multirow[t]{2}{*}{ FP29 } & $\mathbf{n}$ & 54 & 121 & 335 & 61 & 55 & 2 \\
\hline & $\%$ & 8.6 & 19.2 & 53.3 & 9.7 & 8.7 & 0.3 \\
\hline \multirow[t]{2}{*}{ FP30 } & $\mathbf{n}$ & 34 & 40 & 280 & 170 & 102 & 2 \\
\hline & $\%$ & 5.4 & 6.3 & 44.5 & 27.0 & 16.2 & 0.3 \\
\hline \multirow[t]{2}{*}{ FP31 } & $\mathbf{n}$ & 196 & 199 & 103 & 68 & 60 & 2 \\
\hline & $\%$ & 31.2 & 31.6 & 16.4 & 10.8 & 9.5 & 0.3 \\
\hline \multirow[t]{2}{*}{ FP32 } & $\mathbf{n}$ & 26 & 20 & 119 & 234 & 227 & 2 \\
\hline & $\%$ & 4.1 & 3.1 & 18.9 & 37.2 & 36.1 & 0.3 \\
\hline \multirow[t]{2}{*}{ FP33 } & $\mathbf{n}$ & 45 & 55 & 155 & 187 & 184 & 2 \\
\hline & $\%$ & 7.1 & 8.7 & 24.6 & 29.7 & 29.3 & 0.3 \\
\hline \multirow[t]{2}{*}{ FP34 } & $\mathbf{n}$ & 30 & 27 & 133 & 198 & 238 & 2 \\
\hline & $\%$ & 4.7 & 4.3 & 21.1 & 31.5 & 37.9 & 0.32 \\
\hline \multirow[t]{2}{*}{ FP35 } & $\mathbf{n}$ & 98 & 38 & 89 & 103 & 298 & 2 \\
\hline & $\%$ & 15.6 & 6.0 & 14.1 & 16.4 & 47.4 & 0.32 \\
\hline \multirow[t]{2}{*}{ FP36 } & $\mathbf{n}$ & 115 & 70 & 129 & 156 & 156 & 2 \\
\hline & $\%$ & 18.3 & 11.1 & 20.5 & 24.8 & 24.8 & 0.32 \\
\hline \multirow[t]{2}{*}{ FP37 } & $\mathbf{n}$ & 24 & 26 & 180 & 216 & 180 & 2 \\
\hline & $\%$ & 3.8 & 4.1 & 28.6 & 34.3 & 28.6 & 0.32 \\
\hline \multirow[t]{2}{*}{ FP38 } & $\mathbf{n}$ & 57 & 59 & 228 & 125 & 157 & 2 \\
\hline & $\%$ & 9.0 & 9.3 & 36.3 & 19.9 & 25.0 & 0.3 \\
\hline FP39 & $\mathbf{n}$ & 53 & 63 & 338 & 90 & 82 & 2 \\
\hline
\end{tabular}




\begin{tabular}{|c|c|c|c|c|c|c|c|}
\hline Key & & 1 & 2 & 3 & 4 & 5 & Non-respondant \\
\hline & $\%$ & 8.4 & 10.0 & 53.8 & 14.3 & 13.0 & 0.3 \\
\hline \multirow[t]{2}{*}{ FP40 } & $\mathbf{n}$ & 53 & 69 & 292 & 142 & 70 & 2 \\
\hline & $\%$ & 8.4 & 10.9 & 46. & 22.6 & 11.1 & 0.3 \\
\hline \multirow[t]{2}{*}{ FP41 } & $\mathbf{n}$ & 50 & 31 & 149 & 181 & 215 & 2 \\
\hline & $\%$ & 7.9 & 4.9 & 23.7 & 28.8 & 34.2 & 0.3 \\
\hline \multirow[t]{2}{*}{ FP42 } & $\mathbf{n}$ & 62 & 71 & 118 & 153 & 222 & 2 \\
\hline & $\%$ & 9.8 & 11.3 & 18.7 & 24.3 & 35.3 & 0.3 \\
\hline \multirow[t]{2}{*}{ FP43 } & $\mathbf{n}$ & 66 & 55 & 374 & 92 & 39 & 2 \\
\hline & $\%$ & 10.5 & 8.7 & 59.5 & 14.6 & 6.2 & 0.3 \\
\hline \multirow[t]{2}{*}{ FP44 } & $\mathbf{n}$ & 227 & 96 & 206 & 69 & 28 & 2 \\
\hline & $\%$ & 36.1 & 15.2 & 32.8 & 10.9 & 4.4 & 0.3 \\
\hline \multirow[t]{2}{*}{ FP45 } & $\mathbf{n}$ & 93 & 164 & 220 & 87 & 62 & 2 \\
\hline & $\%$ & 14.8 & 26.1 & 35.0 & 13.8 & 9.8 & 0.3 \\
\hline \multirow[t]{2}{*}{ FP46 } & $\mathbf{n}$ & 61 & 81 & 225 & 111 & 148 & 2 \\
\hline & $\%$ & 9.71 & 12.9 & 35.83 & 17.68 & 23.57 & 0.32 \\
\hline \multirow[t]{2}{*}{ FP47 } & $\mathbf{n}$ & 75 & 137 & 213 & 124 & 77 & 2 \\
\hline & $\%$ & 11.9 & 21.8 & 33.9 & 19.7 & 12.2 & 0.32 \\
\hline
\end{tabular}

Note The question key is constructed by FP = pathophysiology the consecutive number of the item (see Annex 1)Scale of Response: 1: Totally Disagree, 2: Partially Disagree, 3: Neither Agree nor Disagree, 4: Partially Agree, 5: Totally Agree Source: Questionnaire to students of Bachelor in Nutrition 2018.

Table 4. Frequency of responses for the assessment of competencies on procedures $(n=622)$

\begin{tabular}{|c|c|c|c|c|c|c|c|}
\hline Key & & 1 & 2 & 3 & 4 & 5 & Non-respondant \\
\hline \multirow[t]{2}{*}{$\mathrm{P} 48$} & $\mathbf{n}$ & 41 & 23 & 253 & 152 & 157 & 2 \\
\hline & $\%$ & 6.5 & 3.6 & 40.2 & 24.2 & 25.0 & 0.3 \\
\hline \multirow[t]{2}{*}{ P49 } & $\mathbf{n}$ & 81 & 65 & 134 & 132 & 21 & 2 \\
\hline & $\%$ & 12.9 & 10.3 & 21.3 & 21.0 & 34.0 & 0.3 \\
\hline \multirow[t]{2}{*}{ P50 } & $\mathbf{n}$ & 69 & 49 & 124 & 120 & 264 & 2 \\
\hline & $\%$ & 10.9 & 7.8 & 19.7 & 19.1 & 42.0 & 0.3 \\
\hline \multirow[t]{2}{*}{ P51 } & $\mathbf{n}$ & 139 & 81 & 331 & 56 & 19 & 2 \\
\hline & $\%$ & 22.1 & 12.9 & 52.7 & 8.9 & 3.0 & 0.3 \\
\hline P52 & $\mathbf{n}$ & 58 & 123 & 273 & 91 & 81 & 2 \\
\hline
\end{tabular}




\begin{tabular}{|c|c|c|c|c|c|c|c|}
\hline Key & & 1 & 2 & 3 & 4 & 5 & Non-respondant \\
\hline & $\%$ & 9.2 & 19.5 & 43.4 & 14.4 & 12. & 0.3 \\
\hline \multirow[t]{2}{*}{ P53 } & $\mathbf{n}$ & 48 & 68 & 236 & 126 & 148 & 2 \\
\hline & $\%$ & 7.6 & 10.8 & 37.5 & 20.0 & 23.5 & 0.3 \\
\hline \multirow[t]{2}{*}{ P54 } & $\mathbf{n}$ & 103 & 33 & 98 & 74 & 318 & 2 \\
\hline & $\%$ & 16.4 & 5.2 & 15.6 & 11.7 & 50.6 & 0.3 \\
\hline \multirow[t]{2}{*}{ P55 } & $\mathbf{n}$ & 79 & 36 & 179 & 85 & 247 & 2 \\
\hline & $\%$ & 12.5 & 5.7 & 28.5 & 13.5 & 39.3 & 0.3 \\
\hline \multirow[t]{2}{*}{ P56 } & $\mathbf{n}$ & 151 & 84 & 285 & 55 & 51 & 2 \\
\hline & $\%$ & 24.0 & 13.3 & 45.3 & 8.7 & 8.1 & 0.3 \\
\hline \multirow[t]{2}{*}{ P57 } & $\mathbf{n}$ & 50 & 52 & 281 & 148 & 95 & 2 \\
\hline & $\%$ & 7.9 & 8.2 & 44.7 & 23.5 & 15.1 & 0.3 \\
\hline \multirow[t]{2}{*}{ P58 } & $\mathbf{n}$ & 43 & 75 & 344 & 92 & 72 & 2 \\
\hline & $\%$ & 6.8 & 11.9 & 54.7 & 14.6 & 11.4 & 0.3 \\
\hline \multirow[t]{2}{*}{ P59 } & $\mathbf{n}$ & 33 & 40 & 352 & 115 & 86 & 2 \\
\hline & $\%$ & 5.2 & 6.3 & 56.0 & 18.3 & 13.6 & 0.3 \\
\hline \multirow[t]{2}{*}{ P60 } & $\mathbf{n}$ & 60 & 93 & 254 & 100 & 118 & 3 \\
\hline & $\%$ & 9.5 & 14.8 & 40.4 & 15.9 & 18.7 & 0.4 \\
\hline \multirow[t]{2}{*}{ P61 } & $\mathbf{n}$ & 34 & 74 & 352 & 75 & 91 & 2 \\
\hline & $\%$ & 5.4 & 11.7 & 56.0 & 11.9 & 14.4 & 0.32 \\
\hline \multirow[t]{2}{*}{ P62 } & $\mathbf{n}$ & 47 & 67 & 359 & 64 & 89 & 2 \\
\hline & $\%$ & 7.4 & 10.6 & 57.1 & 10.1 & 14.1 & 0.32 \\
\hline \multirow[t]{2}{*}{ P63 } & $\mathbf{n}$ & 54 & 73 & 316 & 86 & 97 & 2 \\
\hline & $\%$ & 8.6 & 11.6 & 50.3 & 13.6 & 15.4 & 0.3 \\
\hline \multirow[t]{2}{*}{ P64 } & $\mathbf{n}$ & 30 & 82 & 349 & 85 & 80 & 2 \\
\hline & $\%$ & 4.7 & 13.0 & 55.5 & 13.5 & 12.7 & 0.3 \\
\hline \multirow[t]{2}{*}{ P65 } & $\mathbf{n}$ & 51 & 98 & 320 & 83 & 73 & 3 \\
\hline & $\%$ & 8.1 & 15.6 & 50.9 & 13.2 & 11.6 & 0.4 \\
\hline \multirow[t]{2}{*}{ P66 } & $\mathbf{n}$ & 60 & 72 & 346 & 50 & 98 & 2 \\
\hline & $\%$ & 9.5 & 11.4 & 55.1 & 7.9 & 15.6 & 0.3 \\
\hline \multirow[t]{2}{*}{ P67 } & $\mathbf{n}$ & 71 & 70 & 358 & 50 & 77 & 2 \\
\hline & $\%$ & 11.3 & 11.1 & 57.0 & 7.9 & 12.2 & 0.3 \\
\hline \multirow[t]{2}{*}{ P68 } & $\mathbf{n}$ & 53 & 55 & 374 & 54 & 90 & 2 \\
\hline & $\%$ & 8.4 & 8.7 & 59.5 & 8.6 & 14.3 & 0.3 \\
\hline
\end{tabular}




\begin{tabular}{|c|c|c|c|c|c|c|c|}
\hline Key & & $\mathbf{1}$ & $\mathbf{2}$ & $\mathbf{3}$ & $\mathbf{4}$ & $\mathbf{5}$ & Non-respondant \\
\hline P69 & $\mathbf{n}$ & $\mathbf{4 8}$ & 83 & 251 & 138 & 106 & 2 \\
\hline & $\%$ & 7.6 & 13.2 & 39.9 & 21.9 & 16.8 & 0.3 \\
\hline P70 & $\mathbf{n}$ & 41 & 63 & 365 & 81 & 76 & 2 \\
\hline & $\mathbf{\%}$ & $\mathbf{6 . 5 3}$ & 10.03 & 58.12 & 12.9 & 12.1 & 0.3 \\
\hline P71 & $\mathbf{n}$ & $\mathbf{5 4}$ & 78 & 323 & 76 & 95 & 2 \\
\hline & $\mathbf{\%}$ & $\mathbf{8 . 6}$ & 12.4 & 51.4 & 12.1 & 15.1 & 0.3 \\
\hline
\end{tabular}

Note: The question key is constructed by $\mathrm{P}=$ procedures, the consecutive number of the item (see Annex 1) Response scale: 1: Totally disagree, 2: Partially disagree, 3: Neither agree nor disagree, 4: Partially agree, 5: Totally agree. Source: Questionnaire to students of Bachelor in Nutrition 2018

The scale reliability analysis was performed with the Cronbach alpha statistic (see table 5), with all coefficients greater than 0.7 indicating high reliability. In the same table are included the results of the sum of the scores of each scale by men and women.

Table 5. Descriptives of the sums of scales by sex and Cronbach's Alpha reliability statistics $(\mathrm{n}=622)$

\begin{tabular}{|l|c|c|c|c|c|c|c|}
\hline & & Median & $\mathbf{p 2 5}$ & $\mathbf{p 5 0}$ & $\mathbf{p 7 5}$ & $\mathbf{m i n}$ & max \\
\hline Clinical history & 0.80 & 55.0 & 49 & 53 & 58 & 29 & 87 \\
\hline Physiopathology & 0.73 & 94.4 & 89 & 94 & 100 & 40 & 125 \\
\hline Procedures & 0.86 & 67.7 & 60 & 66 & 72 & 32 & 115 \\
\hline & & & & & & & \\
\hline Women (n=469) & & & & & & & \\
\hline Clinical history & 0.80 & 55.2 & 49 & 53 & 59 & 29 & 87 \\
\hline Physiopathology & 0.72 & 94.5 & 88 & 94 & 100 & 40 & 125 \\
\hline Procedures & 0.85 & 67.2 & 60 & 66 & 72 & 32 & 10 \\
\hline & & & & & & & \\
\hline Hombres (n=153) & & & & & & & \\
\hline Clinical history & 0.79 & 54.5 & 49 & 53 & 58 & 35 & 120 \\
\hline Physiopathology & 0.74 & 94.0 & 89 & 95 & 100 & 45 & 115 \\
\hline Procedures & 0.87 & 69.2 & 61 & 68 & 75 & 34 & \\
\hline
\end{tabular}

Source: Questionnaire to students of Bachelor in Nutrition 2018. 
Figure 1. Main components of the medical history competency assessment scale

\section{Component loadings}

Main components of the medical history competency assessment scale

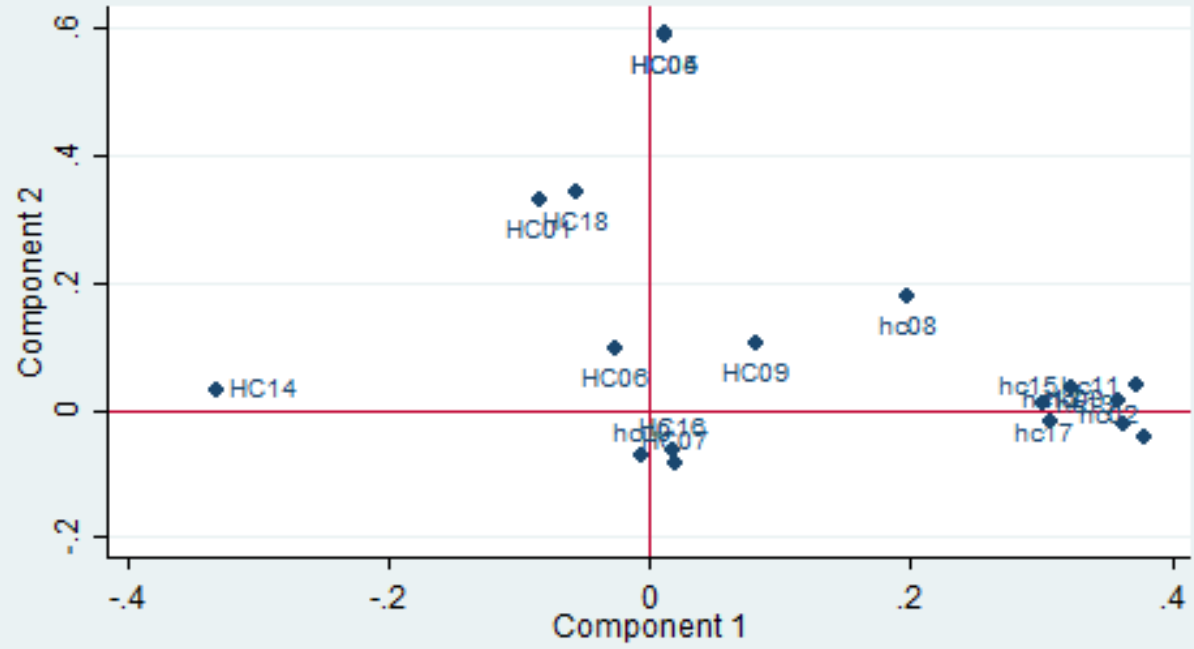

Rotation: orthogonal varimax

Source: Questionnaire to students of Bachelor in Nutrition 2018.

Figure 2. Main Components of the Scale for Assessing Physiopathology Competencies

\section{Component loadings}

Main Components of the Scale for Assessing Physiopathology Competencies

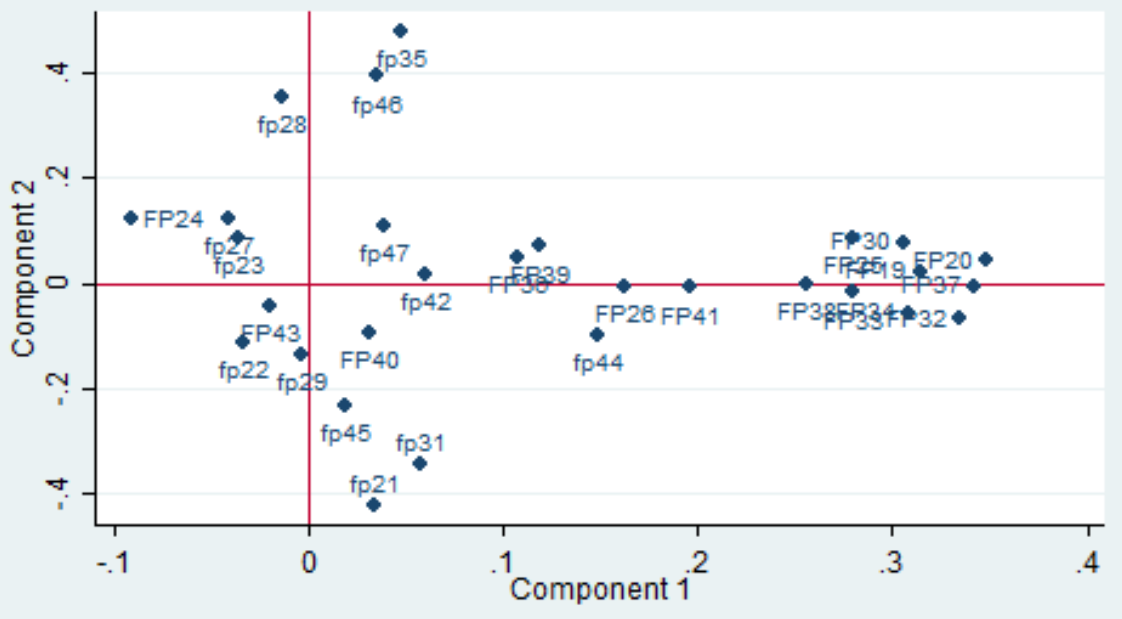

Rotation: orthogonal varimax

Source: Questionnaire to students of Bachelor in Nutrition 2018. 
Figure 3. Main Components of the Scale for Assessing Procedural Competencies

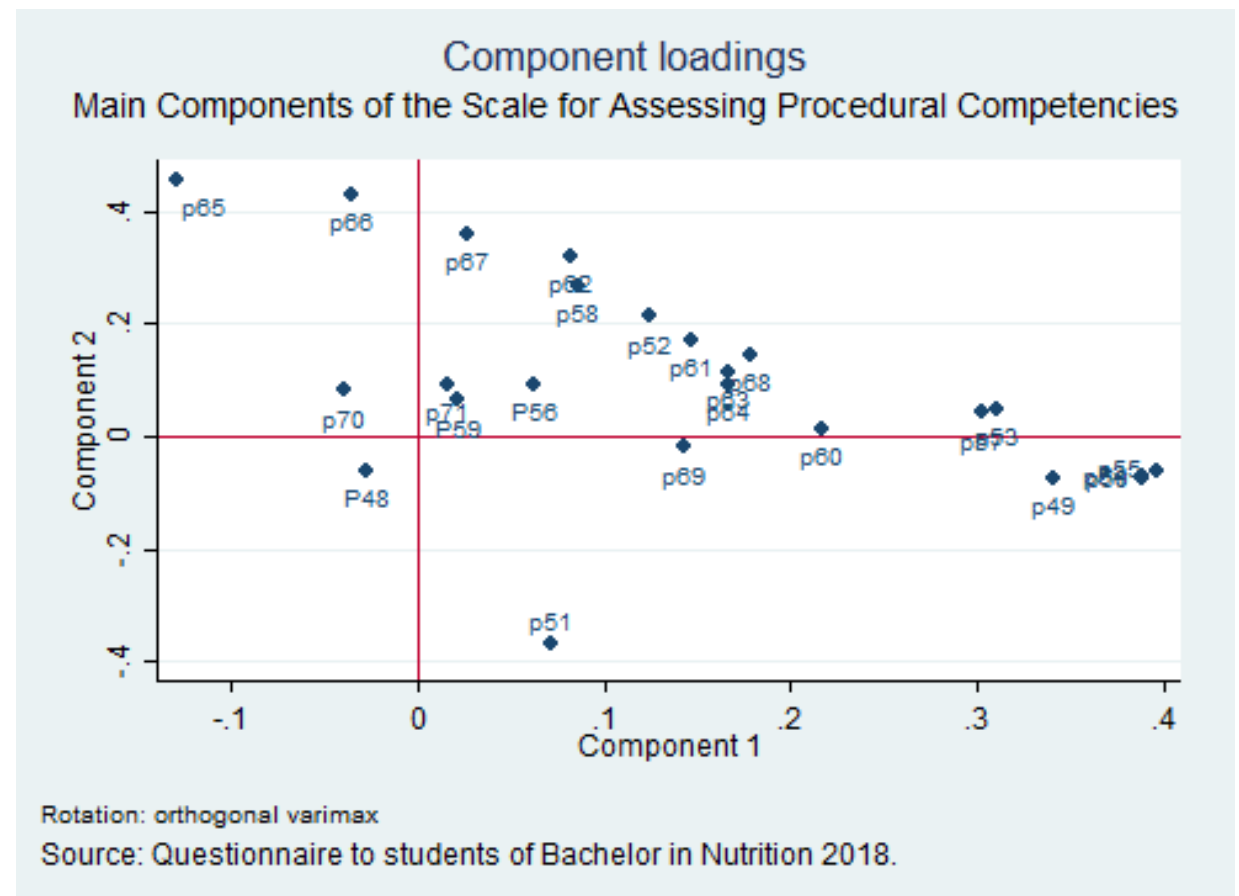

The same that we confirmed with the correlation of Spearman by component, in which we found statistical significance in all the inter item correlations by component (the results of the correlations are not shown), being the only exception the item $\mathrm{HC} 10$ of the clinical history competence $(\mathrm{p}=0.5707)$, which does not keep correlation with the reagent $\mathrm{HCO} 4$ (The clinical record is synonymous with clinical history). Both reagents refer to NOM-004-SSA3-2012, which describes the regulations for the clinical record. However, item $\mathrm{HC10}$ is removed from the questionnaire as confusing. For the physiopathology variable, most of the items showed high correlations $(\mathrm{p}=0.000)$. Finally, for the procedures variable, it presented strong correlations between items and did not show any confusing reagents.

\section{Discussion}

One of the experiences that we had during the obtaining of the data, is that the application of paper questionnaires lends itself to omit answer and to have lost data, although we did not arrive not even to $5 \%$ of lost data, of preference the questionnaires should be applied in line, forcing the answer like obligatory, especially in the sociodemographic variables, in this case it affected to the construction of the socioeconomic index obtaining only a $n=609$ (rate of non answer of $2 \%$ ). 
On the other hand, we could observe that the items that were not correlated with the confirmatory analysis are items FP40-FP24 (p=0.7089), FP29-FP23 ( $\mathrm{p}=0.6869)$, FP45-FP22 ( $\mathrm{p}=0.5483$ ) presented marginal correlations because there is no relationship between the questions, The HC10 and FP42 reagents, the students were not able to answer the correct answer, so we suggest that in future studies are not taken into account and catalogued as confusing (see Annex 1).

The questionnaire designed in this work was validated in a manner very similar to that established by Márquez Sandoval et al (2014 and Villavicencio Martínez (2017). For this case, the method called validation by academic peers or panel of experts was also used, and in the second instance, the statistical method, in the latter, Cronbach's Alpha tests, factor analysis by main components, Spearman's correlation test and analysis of variance were applied. The purpose of instrument validation is to ensure that the designed questionnaire can be subjected to the same criteria of validity and reliability that are required of any measuring instrument.

According to Arribas (2004) a measuring instrument must meet seven characteristics or requirements:

The first one establishes that the instrument must be adequate to the problem to be measured; in this case, the instrument was designed to know and evidence the level of knowledge that the students who take the Nutrition Degree have, from the first to the eighth semester, about basic clinical competencies (clinical history, physiopathology and procedures). Secondly, the instrument must be valid, that is, it must be able to measure those characteristics that are intended to be measured and not others; in this sense, each section of the instrument has items specifically designed and constructed to obtain the necessary information about the knowledge that the students have at the time the instrument is applied in each assessed competence. The third point relates to the reliability and precision of the instrument, that is, the instrument must have a minimum of error when measuring the phenomenon, in this case each competence. The fourth point refers to the sensitivity in the measurement; the instrument must be able to measure the changes both in the different individuals and in the response of the same individual over time. The model proposed in this paper required that this point be fulfilled, because the instrument was subsequently applied to the study groups (natural and experimental) before and after the intervention. The fifth statement refers to the clarity of each dimension of the questionnaire, in such a way that each component contributes to the total understanding of what is intended to be measured independently and as a whole.

The questionnaire was designed with a variable number of items to evaluate each competency, since each of these requires evaluating specific knowledge. This ensured that all the constructs were valid. Very similar to what was done by Márquez et al (2014) and Villavicencio Martínez (2017) in their validation studies, five researchers were invited to participate, three experts in the areas of competence and 
two experts in the area of pedagogy and education. Subsequently, each expert was sent the questionnaire in digital format via e-mail so that each of them could review and make the pertinent observations and/ or modifications. In the first judging session they were asked to evaluate a) the clarity of the reagent, b) the feasibility of the reagent and the ease with which the item can be answered by the student and c) congruence, the degree to which the items correspond to the competence to which they belong. The suggestions and considerations of the experts were taken into account and with the latter the final questionnaire was integrated. Then, a pilot session was run with a group of 10 randomly selected students to verify the clarity, comprehension of the items, response time and their opinion on the questionnaire.

For the clinical history knowledge scale, 4 components were chosen because the explained variance was equal to or greater than 1.3, with a Cronbach Alpha of 0.80, all the items presented high correlation $\mathrm{p}=0.000$; with the exception of item $\mathrm{HC} 10$, which did not present correlation and was considered confusing, because the student did not understand the question. The Bonferroni test was used to compare knowledge by semester (tables are not shown). The result of this test showed that sixth semester students have more knowledge than first to fifth semester students, which is expected. However, this was not the case when the knowledge of the sixth semester students was compared with that of the seventh and eighth semester students. This requires establishing or implementing alternative teaching-learning strategies and study techniques to solve this area of competence.

For the physiopathology variable, almost all the items presented strong correlations with the exception of the reagents FP40-FP24 ( $\mathrm{p}=0.7089)$, FP29-FP23 ( $\mathrm{p}=0.6869)$, FP45-FP22 ( $\mathrm{p}=0.5483$ ) which presented marginal correlations due to the fact that there is no relationship between the questions. Item FP42 was eliminated because it was considered confusing. Regarding the comparison of knowledge when the Bonferroni test was applied per semester again, the sixth semester students have more knowledge about physiopathology than the first to fifth semester students, which is expected.

Seventh and eighth graders have more knowledge than first through fifth graders, but less knowledge than sixth semester graders. This is a result of the fact that sixth semester students may choose to take the elective course 3 Enteral and Parenteral Nutrition and the interest of the majority in obtaining clinical knowledge that is affecting the average results of this specific semester. The content program of this subject considers that pathologies related to clinical nutrition are studied for this reason, so it could result in students in the sixth semester have more knowledge in this area of nutrition.

Finally, the procedures variable, which behaved in a very similar way to the other two competitions, obtained a Cronbach Alpha of 0.86 (see table 5); the significance obtained in the Spearman correlation for the resulting 4 main components, yielded a strong correlation with a value of $\mathrm{p}=0.000$. As for the comparison of knowledge per semester after applying the Bonferroni test, the result was very similar 
to the clinical history and pathophysiology variables. The test showed that sixth semester students have more knowledge about procedures related to clinical nutrition than all other students. Students in the first five semesters have the same knowledge as students in the seventh and eighth semesters, which is an important point to consider because knowledge does not increase and what is worse, seems to decrease.

It is therefore more than clear that students studying for the Bachelor $>$ degree in Nutrition partially possess basic clinical skills. The sixth semester students scored better in knowledge, probably because many of them took the subject twice and some others came from listeners. Possibly this influenced the results of this group of students. However, it is possible to affirm that the instrument measures the phenomenon for which it was created, it is consistent, reliable and self-applicable.

\section{Conclusions}

It was possible to validate the questionnaire and establish which items would be better not to include in the clinical competence evaluation questionnaires. The present work allowed the generation of a diagnostic and evaluation measure of the three basic clinical competencies required in the field of clinical nutrition through the design, construction and validation of a self-application instrument (Likert questionnaire/scale) to evaluate theoretical and practical knowledge. This is proposed as a tool for formative evaluation in the field of nutrition based on the competencies acquired, so that having valid and reliable instruments allows us to comprehensively evaluate the training of students in academic programs, so that in the future the results will be better in terms of the performance of the specialist graduated from the various training institutions.

\section{References}

Boucher, A. and Ste-Marie, L.G. (2014). Toward a competency based medical education curriculum: a training framework (Vol. I). Quebec, Canada: Université de Montréal. URL: https:// wp-portail.med.umontreal.ca/cpass/wp-content/uploads/sites/4/2015/07/CBAFramework UdeM.pdf

Bronfman, M., Castro, V., Guiscafré, H., Castro, R. \& Gutiérrez, G. (1988). Estrategias para amejorar los patrones terapeuticos utilizados en diarrea aguda en unidades de atencion medica primaria. La medición de la desigualdad:una estrategia metodológica. Análisis de las características socieconómicas de la muestra. Archivos de investigación Médica, 19(4), 351-360. 
Canicoba, M., de Baptista, G.A. and Visconti, G. (2013). Funciones y competencias del nutricionista clínico. Documento de consenso. Una revisión de diferentes posiciones de sociedades científicas latinoamericanas. Revista Cubana de Alimentación y Nutrición, 23(1), 146172. URL: https://www.medigraphic.com/pdfs/revcubalnut/can-2013/can1311.pdf

Chambers, M.A. (1998). Some issues in the assessment of clínical practice: a review pf the literature. Journal of Clinical Nursing, 7(3), 201-208. https://doi.org/10.1046/j.1365$\underline{2702.1998 .00121 . x}$

Cook, D.A., Beckman, T.J., Mandrekar, J.N. and Pankratz, V.S. (2011). Internal structure of miniCEX scores for internal medicine residents factor analysis and generalizability. Advances in Health Sciences Education, 15(5), 633-645. https://doi.org/10.1007/s10459-010-9224-9

Cowan, D.T., Norman, I., and Coopamah, V.P. (2005). Competence in nursing practice: a controversial concept--a focused review of literature. Nurse Educ Today; 25(5): 355-62. DOI: 10.1016/j.nedt.2005.03.002

Daniel, W. (2005). Bioestadística: base para el análisis de la ciencias de a salud (Vol. I). Ciudad de México, D.F., México: Limusa Noriega.

De Zousa Cruz, M.C., Mariscal Crespo, MI. (2016). Competencias y entorno clinico de aprendizaje en enfermería: autopercepcion de estudiantes avanzados de Uruguay. Enfermería Global \#41; 15(1): 121-134. URL: https://revistas.um.es/eglobal/issue/view/14421

Defloor, T. Van Hecke, A., Verhaeghe, S., Gobert, M., Darras, E. and Grypdonck, M. (2006). The clinical nursing competences and their complexity in Belgian general hospitals. Journal of Advanced Nursing, 56(6), 669-678. https://doi.org/10.1111/j.1365-2648.2006.04038.x

Díaz-Lorenzo, T., González-Domínguez, A., Calzadilla-Cambará, A., Morejón-Martín, P., Fleitas, A., Rodríguez-Suárez, A. and Portal-Pineda, J. (2011). Organización del proceso docente de la Licenciatura de Nutrición en Cuba. Revista Cubana de Alimentación y Nutrición (RCAN), 21(1), 110-120. URL: http://revalnutricion.sld.cu/index.php/rcan/article/ view $/ 551 /$ pdf 55

Dix, G. and Hughes, S. (2005). Teaching students in the classroom and clinical skills environment. Nursing Standard, 19(35), 41-47. doi: 10.7748/ns2005.05.19.35.41.c3863

Eraut, M. (1998). Concepts of conpetence. Journal of Interprofessional Care, 12(2), 127-139. https://doi.org/10.3109/13561829809014100 
Freeth, D. and Nicol, M. (1998). Learning clinical skills: an interprofessional approach. Nurse Education Today, 18(6), 455-461. https://doi.org/10.1016/S0260-6917(98)80171-8

García-García, J.A., González-Martínez, J.F., Estrada-Aguilar, L., Uriega-González, P.S. (2010). Educación médica basada en competencias. Rev Med Hosp Gen Mex; 73 (1): 57-69. URL: https://www.medigraphic.com/pdfs/h-gral/hg-2010/hg101k.pdf

Márquez-Sandoval, Y.F., Salazar-Ruiz, E.N., Macedo-Ojeda, G., Altamirano-Martínez, M.B., Bernal-Orozco, M.F., Salas-Salvadó, J. and Vizmanos-Lamotte, B. (2014). Diseño y validación de un cuestionario para evaluar el comportaminetoalimentario en estudiantes mexicanos del área de la salud. Nutrición Hospitalaria, 30(1), 153-164. URL: http:// scielo.isciii.es/pdf/nh/v30n1/20originalvaloracionnutricional01.pdf

Matas, A. (2018). Diseño del formato de escalas tipo Likert: un estado de la cuestión. Revista Electrónica de Investigación Educativa, 20(1), 38-47. https://doi.org/10.24320/redie.2018.20.1.1347

McGaughey, J. (2004). Standardizing the assessmente of clínical competence: an overview of intensive care cousre design. Nursing in Critical Care, 9(5), 238-246. https://doi.org/10.1111/ j.1362-1017.2004.00082.x

Moreno-Olivos, T. (2010). El currículo por competencias en la universidad: Más ruido ue nueces. Revista de la Educación Superior, 39(154), 77-90. URL: http://publicaciones.anuies. mx/pdfs/revista/Revista154 S2A1ES.pdf

O’Neill, A. and McCall, J.M. (1996). Objectively assessing nursing practices. a curricular development. Nurse Education Today, 12(2), 121-126. https://doi.org/10.1016/S0260$\underline{6917(96) 80068-2}$

Quero-Virla, M. (Mayo-Agosto de 2010). Confiabilidad y y Coeficiente de Alpha de Cronbach. Telos: Revista de Estudios Interdisciplinarios en Ciencias Sociales, 12(2), 248-252. URL: https://dialnet.unirioja.es/descarga/articulo/3335380.pdf

Rangel-Torrijo, H. (2015). Reseña del libro: Corvalán, O., Tardif, J. and Montero, P. (2013). Metodologías para la innovación curricular universitaria basada en el desarrolloo de competencias. Perfilies Educativos, 37(147): 228-234. URL: http://www.iisue.unam.mx/ perfiles/articulo/2015-147.pdf

Regehr, G., Eva, K., Ginsburg, S., Halwani, Y. and Sidhu, R. (2011). 13 Assessment in Postgraduate Medical Education: Trends and Issues in Assessment in the Workplace. Members 
of the FMEC PG consortium. AFMC, Canada. URL: https://afmc.ca/pdf/fmec/13 Regehr Assessment.pdf

Rivera-Michelena, N.M., Pernas-Gómez, M. and Nogueira-Sotolongo, M. (2017). Un sistema de habilidades para la carrera de Medicina, su relación con las competencias profesionales. Una mirada actualizada. Educación Médica Superior, 31(1), 215-238. URL: http:// www.ems.sld.cu/index.php/ems/article/view/856/483

Rushton, P. and Eggett, D. (2003). Comparison of written and oral examinations in a baccalaurate medical surgical nursing course. Journal of Professional Nursing, 19(3), 142-148. DOI: 10.1016/s8755-7223(03)00049-8

Sánchez L., García-Lorda, P., Bulló, M., Balanzà, R., Megias, I. and Salas-Salvadó, J. (2003). Le enseñanza de la nutrición en las facultades de medicina: situación actual. Nutrición Hospitalaria, 18(3), 153-158. URL: http://scielo.isciii.es/pdf/nh/v18n3/original3.pdf

Secretaria de Salud. (18 de septiembre de 2012). Norma Oficial Mexicana NOM-022-SSA3-2012, condiciones para terapias de infusión. Diario oficial de la Federación, México.

Secretaria de Salud. (19 de octubre de 1998). Norma Oficial Mexicana NOM-149-SSA1-1996, especificaciones sanitarias para sondas de alimentación. Diario oficial de la Federación, México.

Secretaria de Salud. (4 de marzo de 2011). Norma Oficial Mexicana NOM-249-SSA1-2010, Mezclas estériles: nutricionales, medicamentosas e instalaciones para su preparación. Diario oficial de la Federación, México.

Secretaria de Salud. (9 de junio de 2012). Norma Oficial Mexicana NOM-004-SSA3-2012, del expediente clínico. Diario oficial de la Federación, México.

Sepúlveda-Vildósola, A.C., Gaspar-López, N., Reyes-Lagunes, L.I. and Gonzalez-Cabello, H.J. (2014). Confiabilidad y Validez de un instrumento de evaluación de competencia clínica integral de médicos residentes. Revista Médica del Instituto Mexicano del Seguro Social, 53(1), 30-39. URL: https://www.medigraphic.com/pdfs/imss/im-2015/im151e.pdf

Sierra-Figueredo, S., Pernas-Gómez, M., Fernández-Sacasas, J.A., Diego-Cobelo, J.M., MirallesAguilera, E., de la Torre-Castro, G., González-García, N., Cardona-Monteagudo, M. and Acosta-Hernández, Z. (2010). Modelo Metodológico para el diseño y aplicación de esrtaegias curriculaes en ciencias médicas. Revista Cubana de Educación Media Superior(24), 33-41. URL: http://scielo.sld.cu/pdf/ems/v24n1/ems05110.pdf 
Tardif, J. (2006). L'évaluation des compétences: Documenter le parcours de développement. CHENELIERE, Montreal, Canada.

Tobón, S. (2007). El enfoque complejo de las competencias y el diseño curricular por ciclos propedéuticos. Acción Pedagógica(16), 14-25. URL: https://dialnet.unirioja.es/descarga/ articulo/2968540.pdf

UAEM. (2010). Plan de estudios de la Licenciatura en Nutrición (Vol. I). Cuernavaca, Morelos, México: Universidad Autónoma del Estado de Morelos (UAEM).

Universidad Autónoma del Estado de Morelos. (2010). Plan de estuduos de la licenciatura en nutrición (1ra Edición ed., Vol. I). Cuernavaca, Morelos, México.

Villavicencio-Martínez, R.A. and Luna-Serrano, E. (2017). Desarrollo de un cuestionario de evaluación de la competencia de supervisión clínica en Medicina. Revista Iberoamericana de Educación Superior, 8(22), 1-12. URL: http://www.scielo.org.mx/pdf/ries/v8n22/20072872-ries-8-22-00144.pdf

Walsh, M., Bailey, P.H., and Koren, I. (2009). Objetive structured clinical evaluation of clinical competence: an integrative review. Journal of Advanved Nursing, 65(8), 1584-1595. doi: 10.1111/j.1365-2648.2009.05054.x

Watson, R., Stimpson, A., Topping, A. and Porock, D. (2002). Clinical competence of assessment in nursing: a systematic review of the literature. Journal of Advanced Nursing, 39(5), 421-431. DOI: 10.1046/j.1365-2648.2002.02307.x 